\title{
MYCORRHIZAE OF LANDSCAPE TREES PRODUCED IN RAISED BEDS AND CONTAINERS
}

\author{
by David Sylvia, ${ }^{1}$ Abid Alagely, ${ }^{2}$ Donald Kent, ${ }^{3}$ and Roy Mecklenburg ${ }^{4}$
}

\begin{abstract}
Mycorrhizal associations provide a linkage between tree roots and the soil, thereby contributing to the tolerance of trees to environmental stresses. Little, however, is known about the mycorrhizal status or dependency of many landscape trees. The objective of this study was to quantify mycorrhizal root colonization and spore formation on a diverse collection of ornamental tree species grown in raised beds or containers at an established tree farm in central Florida. In addition, root diameters were measured to determine if there was a relationship between this parameter and mycorrhizal formation. A total of 23 tree species were sampled; 9 were present both in containers and raised beds, 6 species were present in containers only, and 8 species were present as embedded plants only. The proportion of root length colonized by mycorrhizal fungi ranged from $0 \%$ to $83 \%$. Mean arbuscular mycorrhizal spore numbers ranged from $<20$ to nearly 500 spores $100 \mathrm{~g}^{-1}\left(3.5 \mathrm{oz}^{-1}\right)$. Mean root diameters ranged from $<500$ to $>1,000 \mu \mathrm{m}(0.0197$ to 0.0394 in.). No relationship was found between root coarseness and mycorrhizal root colonization or sporulation. The majority of trees formed mycorrhizae of the arbuscular type. Five species in the family Pinaceae or Fagaceae had the potential to form ectomycorrhizae; however, they were poorly colonized. Future research should be directed toward understanding the importance of mycorrhizae to landscape trees, including effects on tree survival and growth and the effect of fertilizer and pesticide applications on mycorrhizal development.
\end{abstract}

Under natural conditions, the fine roots of woody plants are colonized by mycorrhizal fungi (Brundrett 1991; Haselwandter and Bowen 1996). The resulting symbiotic associations provide a critical linkage between tree roots and the soil. Mycorrhizae are characterized by the movement of plant-produced carbon compounds to the fungus and fungal-acquired nutrients to the tree. Mycorrhizae usually produce a proliferation of fungal biomass both in the root and in the soil (Read 1992). The soilborne, or extramatrical, hyphae take up nutrients from the soil solution and transport them to the root (George et al. 1992). By this mechanism, mycorrhizae increase the effective absorptive surface area of a tree (O'Keefe and Sylvia 1991). As a result, mycorrhizal trees may have better establishment and greater tolerance of environmental stresses than nonmycorrhizal trees (Sylvia and Williams 1992). For example, Garbaye and Churin (1996) found that ectomycorrhizal (EM) inoculation improved growth of Tilia tomentosa in an urban setting, and Johnson et al. (1980) reported that arbuscular mycorrhizal $(A M)$ inoculation improved growth of several woody ornamentals even under high-fertility conditions.

Disturbances (e.g., mining, tillage, and construction activity) and certain cultural practices (e.g., high fertilization and pesticide use) may greatly reduce the number of mycorrhizal propagules in soil (Doerr et al. 1984; Thompson 1987; Johnson and Pfleger 1992; McGonigle and Miller 1993). Low propagule numbers may result in poor mycorrhizal development on plants and subsequent poor growth of mycorrhizal-dependent plant species placed in the landscape. Baylis (1975) first proposed that coarse-rooted plants are more dependent on mycorrhizae for nutrient uptake than are fine-rooted plants. Pope et al. (1983) confirmed this hypothesis in 4 hardwood tree species, finding that plant root fibrosity was inversely related to mycorrhizal dependency.

Trees are usually colonized by either arbuscular mycorrhizae, ectomycorrhizae, or in a few cases by both types of mycorrhizae (Haselwandter and Bowen 1996). However, little is known about the mycorrhizal status or dependency of many important landscape trees. Landscape trees are often grown in a nursery under high fertility and water conditions and subsequently transplanted to disturbed sites. The purpose of our study was to determine the extent of mycorrhizal development (root colonization and sporulation) on selected trees grown in containers and raised beds at an established tree farm in central Florida. In addition, we evaluated root coarseness (as indicated by root diameter) as a predictor of mycorrhizal development. 


\section{Materials and Methods}

Sample collection. A total of 23 tree species were sampled between May 3 and June 8, 1996, from an established tree farm at Walt Disney World in Lake Buena Vista, Florida (Table 1). The majority of the trees were of exotic origin, with only Magnolia grandiflora, Persea borbonia, and the 3 Quercus species being native to central Florida. Nine species were sampled from plants grown both in containers and raised beds, 6 species were sampled from containers only, and the remaining 8 species were sampled from embedded plants only. Five trees were sampled from each tree species in each growth environment where it occurred.

Containers $(60 \mathrm{~cm}$ high and $70 \mathrm{~cm}$ in diameter, or $24 \times 28$ in.) were constructed of perforated and corrugated aluminum sheets formed into cylinders and secured with 2 sheet metal screws. Containers were placed on pieces of woven plastic cloth (to provide drainage and restrict root growth into soil) and filled with a blend of approximately $35 \%$ sandy topsoil, 35\% green pine bark,

Table 1. Landscape trees and growth environment (container or raised bed) sampled from an established tree farm at Walt Disney Worid between May 3 and June 8, 1996.

\begin{tabular}{|c|c|c|c|c|}
\hline Latin binomial & Family & Common name & Container & Raised bed \\
\hline Acacia farnesiana & Leguminosae & sweet acacia & + & + \\
\hline Albizia julibrissin & Leguminosae & silk tree & + & \\
\hline Bambusa glaucescens & Bambuseae & hedge bamboo & & + \\
\hline B. ventricosa & Bambuseae & Buddha's belly & & + \\
\hline Cedrus deodara & Pinaceae & deodora cedar & & + \\
\hline Cinnamomum camphora & Lauraceae & camphor tree & + & + \\
\hline Elaeocarpus decipiens & Elaeocarpaceae & $\mathrm{NCN}$ & + & + \\
\hline Gordonia lasianthus & Theaceaea & loblolly bay & + & \\
\hline Ginkgo biloba & Ginkgogaceae & ginkgo & + & + \\
\hline Koelreuteria elegans & Sapindaceae & golden rain tree & + & \\
\hline Ligustrum japonicum & Oleaceae & Japanese privet & & + \\
\hline L. lucidum & Oleaceae & glossy privet & + & + \\
\hline Livistona decipiens & Palmaceae & $\mathrm{NCN}$ & & + \\
\hline Magnolia grandiflora & Magnoliaceae & southern magnolia & + & + \\
\hline Persea borbonia & Lauraceae & redbay & & + \\
\hline Phyllostachys bambusoides & Bambuseae & timber bamboo & + & \\
\hline Quercus laurifolia & Fagaceae & laurel oak & & + \\
\hline Q. myrisinifolia & Fagaceae & myrtle oak & + & \\
\hline Q. virginiana & Fagaceae & live oak & & + \\
\hline Robinia idahoensis & Leguminosae & purple robe Idaho & + & \\
\hline Tabebuia chrysotricha & Bignoniaceae & golden trumpet tree & + & + \\
\hline Taxodium mucronatum & Pinaceae & Montezuma cypress & + & + \\
\hline Ulmus parvifolia & Uimaceae & Chinese elm & + & + \\
\hline
\end{tabular}

and $30 \%$ biosolids compost. Five-gallon-size trees were purchased from commercial nurseries and transplanted into the containers a minimum of 2 years prior to sampling. Containers were irrigated daily with a spray stake emitter.

Trees grown in the ground were on raised beds (30 $\mathrm{cm}$ [12 in.] high) in a sandy soil that was topdressed annually with approximately $5 \mathrm{~cm}$ (2 in.) of biosolids compost. Trees were planted as either 5- or 10-gallon-size plants and had been grown in the raised beds for a minimum of 2 years prior to sampling. Embedded trees were irrigated daily by overhead irrigation.

The same fertilizer regime was used for trees grown in containers and in raised beds. Fertility was maintained by the application of 10-5-10 granular fertilizer $(2.5 \%$ ammoniacal N, $3.51 \%$ soluble organic N, $3.99 \%$ water-insoluble $\mathrm{N}$, $1.51 \% \mathrm{Mg}$, and $1.55 \% \mathrm{Fe}$ ) at the rate of $0.97 \mathrm{~kg}$ $\mathrm{N} 100 \mathrm{~m}^{-2}$ (2 lb $\left.1,000 \mathrm{ft}^{-2}\right)$ for each of 3 applications made each year during February, June, and September. The fertilizer was broadcast on the top of the containers or placed in a $1.8-\mathrm{m}$-wide (6-ft) band adjacent to embedded trees.

Samples were collected by driving a sharpened steel pipe $(4.5 \mathrm{~cm}$ in diameter, or $1.8 \mathrm{in}$.) to a depth of $25 \mathrm{~cm}$ (9.8 in.). Two samples were collected within each container or, for trees grown in raised beds, around the dripline of each tree. Samples were placed in plastic bags and kept cool until they were returned to the laboratory, where they were stored at $4^{\circ} \mathrm{C}\left(39^{\circ} \mathrm{F}\right)$. In the laboratory, the 2 samples from each tree were combined and mixed thoroughly before a $100 \mathrm{~g}$ (3.5-oz) subsample was removed for further processing. Roots and spores 
of AM fungi were extracted from the subsample by decanting and wet sieving (sieve size ranged from 45 to $1,000 \mu \mathrm{m}$, or 0.002 to 0.039 in.), followed by sucrose-density-gradient centrifugation for separation of spores (Sylvia 1994).

Clearing and staining protocols. Roots collected on the 1,000- $\mu \mathrm{m}(0.039-$ in.) sieve were cleared in $1.8 \mathrm{MKOH}$ for 1 hour at $80^{\circ} \mathrm{C}\left(176^{\circ} \mathrm{F}\right)$ and washed in 3 changes of water. Roots of woody plants are often difficult to clear because they contain high levels of phenolic materials; therefore, 2 additional protocols subsequent to $\mathrm{KOH}$ treatment were evaluated on one sample from each plant species: 1) $30 \% \mathrm{H}_{2} \mathrm{O}_{2}$ for $10 \mathrm{~min}$ utes at $50^{\circ} \mathrm{C}\left(122^{\circ} \mathrm{F}\right)$ and 2) $3 \% \mathrm{NaOCl}$, acidified with several drops of $5 \mathrm{M} \mathrm{HCl}$, for 50 seconds at ambient temperature. Following clearing, roots were washed in 5 changes of water, acidified with $\mathrm{HCl}$, and then stained with trypan blue for 30 minutes at $80^{\circ} \mathrm{C}\left(176^{\circ} \mathrm{F}\right)$ (Sylvia 1994). Clearing with $\mathrm{NaOCl}$ proved most satisfactory and was used for the preparation of the remainder of the samples.

Mycorrhizal root colonization, root diameter, and AM spore number. Cleared roots were spread evenly on a scribed, plastic Petri dish and total and colonized root lengths were estimated with a dissecting microscope using the gridline-intersect method (Giovannetti and Mosse 1980). Intersections were scored positive for AM only if arbuscules or vesicles were present, and positive for EM only if evidence of a fungal mantle or Hartig net was observed. Any questionable fungal structures within the roots were evaluated at $400 \times$ magnification with a compound microscope. To quantify fine-root diameters, 10 randomly collected root pieces of each species were mounted in water on a microscope slide and measured at $400 \times$ magnification with an eyepiece micrometer. The supernatant of the final centrifuge wash was placed in a scribed Petri dish, and AM spores were counted under a dissecting microscope. Again, any questionable structures were further evaluated at $400 \times$ magnification.

\section{Results}

Mycorrhizal root colonization. The proportion of root length colonized by mycorrhizal fungi ranged from $0 \%$ for Cinnamomum camphora (in containers), UImus parvifolia, and 2 Quercus species, to $83 \%$ for Bambusa ventricosa growing in raised beds (Figure 1A, Table 2, and Table 3 ). The growth environment did not have a consistent effect on root colonization (Figure 1A).

The majority of trees sampled formed mycorrhizae of the arbuscular type. We did, however, sample 5 species that are in plant families dominated by ectomycorrhizae. Quercus laurifolia and $Q$. virginiana were not colonized (Table 3 ). Quercus myrisinifolia (Table 2) and Cedrus deodara (Table 3 ) had low levels of colonization, and the colonized regions had distinct mantles of an ectomycorrhiza. In contrast, Taxodium mucronatum was colonized by AM fungi in both containers and in raised beds.

AM spore number. Spores of AM fungi were present in all samples, but mean numbers ranged from $<20$ to nearly 500 spores $100 \mathrm{~g}^{-1}\left(3.5 \mathrm{oz}^{-1}\right)$ (Figure 1B, Table 2, and Table 3). More than 75\% of the spores observed were Glomus spp., with the remainder belonging to the family Gigasporineae. Samples from containers tended to have more spores ( $146 \pm 75$ spores $100 \mathrm{~g}^{-1}$, or $3.5 \mathrm{oz}^{-1}$ ) than samples from the raised beds (76 \pm 24 spores $100 \mathrm{~g}^{-1}$, or $3.5 \mathrm{oz}^{-1}$ ).

Fine root diameter. Mean root diameters ranged from $<500 \mu \mathrm{m}$ (0.019 in.) for Ulmus parvifolia, Bambusa spp., and Gordonia lasianthus to >1,000 $\mu \mathrm{m}$ (0.039 in.) for Quercus virginiana, Robinia idahoensis, and Taxodium mucronatum (Figure 1C, Table 2, and Table 3). When comparing plants growing in both environments, samples from the raised beds had greater root diameters $(914 \pm 97 \mu \mathrm{m}$, or $0.036 \pm 0.004 \mathrm{in}$.) than samples from containers $(684 \pm 65 \mu \mathrm{m}$, or $0.027 \pm 0.003$ in.). No significant relationship was found between root coarseness and root colonization or AM sporulation.

\section{Discussion}

The sampled trees differed widely in the proportion of root length colonized by mycorrhizal fungi and associated AM sporulation. Because the trees were grown under similar conditions within growth environments, these data suggest some host control on mycorrhizal interactions (Graham 

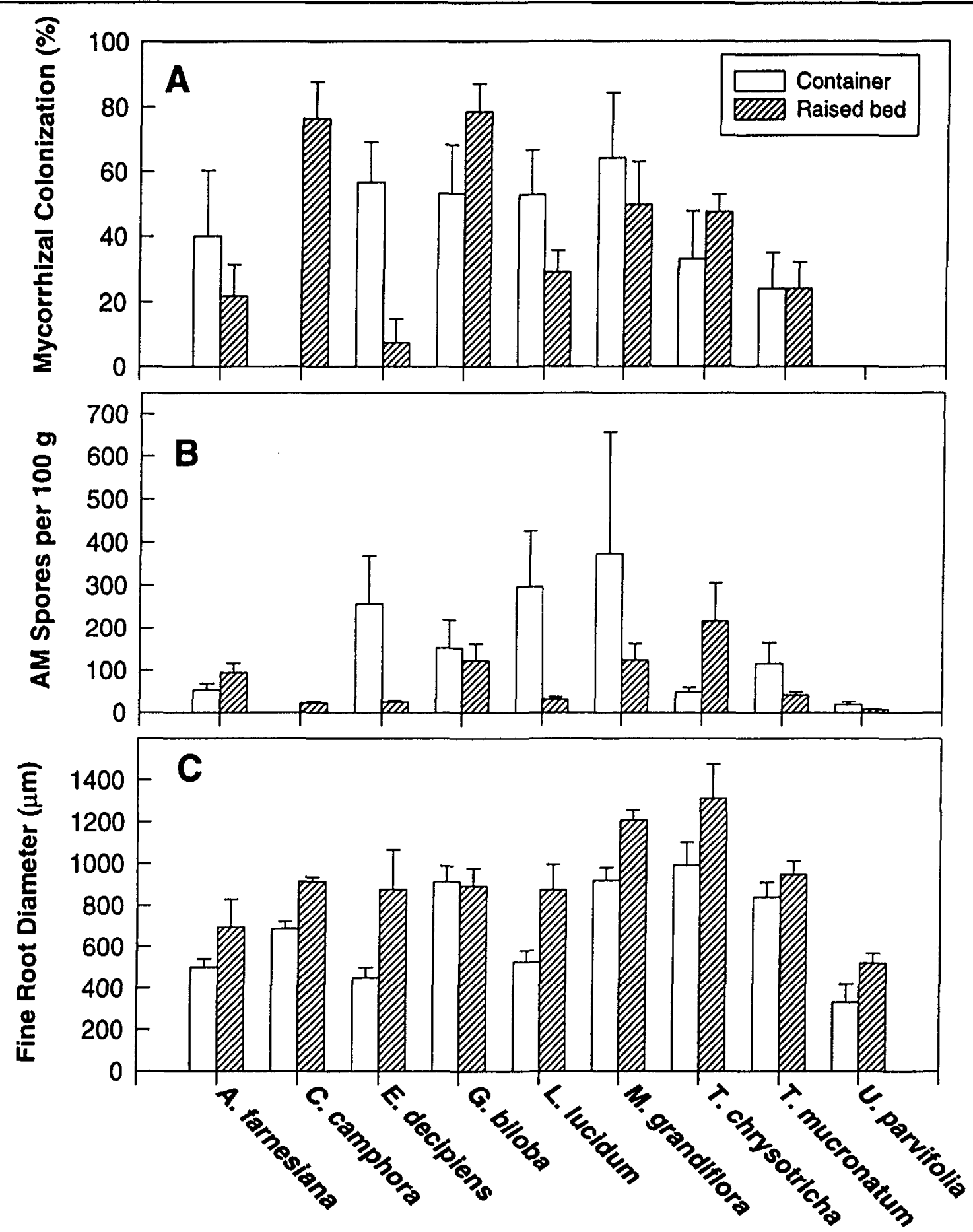

Figure 1. Mycorrhizal root colonization (A), AM spore number (B), and root diameter (C) of landscape trees samples both in containers and raised beds at Walt Disney World on May 3 or June 8, 1996. Bars represent the mean of 5 replicates \pm S.E.M. 
Table 2. Mycorrhizal root colonization, AM spore numbers, and fine root diameters of landscape trees sampled in containers only at Walt Disney World between May 3 and June 8, 1996. Values represent the mean of 5 replicates \pm S.E.M.

\begin{tabular}{llll}
\hline Host plant & $\begin{array}{l}\text { AM root } \\
\text { colonization } \\
(\%)\end{array}$ & $\begin{array}{l}\text { AM spore } \\
\text { number } \\
\left(100 \mathrm{~g}^{-1}\right)\end{array}$ & $\begin{array}{l}\text { Fine root } \\
\text { diameter } \\
(\mu \mathrm{m})\end{array}$ \\
\hline A. julibrissin & $12 \pm 3$ & $102 \pm 29$ & $692 \pm 84$ \\
G. lasianthus & $13 \pm 6$ & $103 \pm 37$ & $505 \pm 48$ \\
K. elegans & $8 \pm 2$ & $116 \pm 52$ & $624 \pm 19$ \\
P. bambusoides & $53 \pm 12$ & $176 \pm 62$ & $836 \pm 118$ \\
Q. myrisinifolia & $6 \pm 2$ & $40 \pm 14$ & $611 \pm 143$ \\
R. idahoensis & $14 \pm 9$ & $498 \pm 235$ & $537 \pm 66$ \\
\hline
\end{tabular}

Table 3. Mycorrhizal root colonization, AM spore numbers, and fine root diameters of landscape trees sampled in raised beds only at Walt Disney World between May 3 and June 8, 1996. Values represent the mean of 5 replicates \pm S.E.M.

\begin{tabular}{llll}
\hline Host plant & $\begin{array}{l}\text { AM root } \\
\text { colonization } \\
(\%)\end{array}$ & $\begin{array}{l}\text { AM spore } \\
\text { number } \\
\left(100 \mathrm{~g}^{-1}\right)\end{array}$ & $\begin{array}{l}\text { Fine root } \\
\text { diameter } \\
(\mu \mathrm{m})\end{array}$ \\
\hline B. glaucescens & $48 \pm 5$ & $35 \pm 19$ & $556 \pm 71$ \\
B. ventricosa & $83 \pm 6$ & $234 \pm 85$ & $552 \pm 89$ \\
C. deodara & $3 \pm 1$ & $176 \pm 53$ & $907 \pm 72$ \\
L. japonicum & $78 \pm 7$ & $90 \pm 29$ & $835 \pm 144$ \\
L. decipiens & $61 \pm 8$ & $18 \pm 7$ & $1008 \pm 160$ \\
P. borbonia & $23 \pm 17$ & $73 \pm 33$ & $845 \pm 96$ \\
Q. laurifolia & 0 & $48 \pm 16$ & $639 \pm 50$ \\
Q. virginiana & 0 & $48 \pm 5$ & $1110 \pm 85$ \\
\hline
\end{tabular}

and Eissenstat 1994). However, other factors such as variable inoculum density may have also contributed to differing levels of root colonization. For example, the trees were originally obtained from several different nurseries and likely had different exposures to mycorrhizal inoculum prior to their establishment at the tree farm.

The one host parameter we measured, root coarseness (as indicated by root diameter), was not a good predictor of mycorrhizal colonization or sporulation. However, one should not conclude that root coarseness is not related to mycorrhizal function because the absolute amount of colonization may not be directly related to nutrient uptake efficiency or other measures of functionality (Jakobsen 1994). Nonetheless, even though we do not expect to find a direct relationship between root colonization and mycorrhizal function, main- taining some "critical level" of colonization is important for obtaining a mycorrhizal response. Many factors affect the function of mycorrhizae in the field, so a definitive critical level cannot be given. Future research, however, should be directed toward defining a minimum level of inoculum and root colonization that is required to achieve a desired mycorrhizal response.

The ectomycorrhizal hosts were especially low in colonization. Cultural practices may have a negative impact on ectomycorrhizal development. Relatively low AM spore numbers (overall mean of approximately 1 spore $\mathrm{g}^{-1}$, or $0.035 \mathrm{oz}^{-1}$ ) also suggest that cultural practices are impairing function of AM fungi in the tree farm. High rates of fertilization with inorganic nutrients and pesticides are known to inhibit mycorrhizal development (Nemec 1987). Use of less readily available fertilizers such as rock phosphate (Graham and Timmer 1985; Asmah 1995) and careful selection of compatible pesticides (Trappe et al. 1984; Moorman 1989) should be considered to achieve optimal mycorrhizal development.

Where root colonization is very low or absent, inoculation with a compatible fungus may be beneficial. Even in situations where root colonization is higher, inoculation may still be appropriate. It is important to distinguish infectiveness (amount of colonization) and effectiveness (plant response to colonization). Mycorrhizal fungi differ widely in the level of colonization they produce in a root system as well as in their impact on nutrient uptake and plant growth (Burgess et al. 1993; Mcarthur and Knowles 1993; Sylvia et al. 1993; Newsham et al. 1995). High nutrient levels may actually provide a selective pressure for ineffective fungi (Johnson 1993), resulting in colonization but no subsequent benefit to the host. Therefore, screening trials are a necessary prerequisite for recommending inoculation of trees with specific mycorrhizal fungi.

To effectively manage mycorrhizae for the benefit of landscape trees, arborists need to understand the 1) extent and diversity of mycorrhizal fungi associated with their plants, 2) mycorrhizal responsiveness of different trees species, and 3 ) impact of various cultural practices on mycorrhizal function. In this study, we addressed only the first 
concern. Further research is needed to understand the importance of mycorrhizae to landscape trees including effects on tree survival and growth, and the effect of fertilizer and pesticide applications on mycorrhizal development.

\section{Literature Cited}

Asmah, A.E. 1995. Effect of phosphorus source and rate of application on VAM fungal infection and growth of maize (Zea mays L). Mycorrhiza 5: 223-228.

Baylis, G.T. 1975. The magnolioid mycorrhiza and mycotrophy in root systems derived from it, pp 373 389. In Sanders, F.E., B. Mosse, and P.B. Tinker (Eds.). Endomycorrhizas. Academic Press, New York, NY.

Brundrett, M.C. 1991. Mycorrhizas in natural ecosystems, pp 171-213. In Begon, M., A.H. Fitter, and $A$. MacFadyen (Eds.). Advances in Ecological Research vol. 21. Academic Press, New York, NY.

Burgess, T.I., N. Malajczuk, and T.S. Grove. 1993. The ability of 16 ectomycorrhizal fungi to increase growth and phosphorus uptake of Eucalyptus globulus Labill. and E. diversicolor F.-Muell. Plant Soil 153:155-164.

Doerr, T.B., E.F. Redente, and F.B. Reeve. 1984. Effects of soil disturbance on plant succession and levels of mycorrhizal fungi in a sagebrushgrassland community. J. Range Manage. 37:135139.

Garbaye, J., and J.L. Chruin. 1996. Effects of ectomycorrhizal inoculation at planting on growth and foliage quality of Tilia tomentosa. J. Arboric. 22:29-34.

George, E., K.U. Häussler, S.K. Kothari, X.-L. Li, and H. Marschner. 1992. Contribution of mycorrhizal hyphae to nutrient and water uptake of plants, $p p$ 43-47. In Read, D.J., D.H. Lewis, A.H. Fitter, and I.J. Alexander (Eds.). Mycorrhizas in Ecosystems. CAB International, Wallingford, UK.

Giovannetti, M., and B. Mosse. 1980. An evaluation of techniques for measuring vesicular arbuscular mycorrhizal infection in roots. New Phytol. 84: 489-500.

Graham, J.H., and D.M. Eissenstat. 1994. Host genotype and the formation and function of VA mycorrhizae. Plant Soil 159:179-185.

Graham, J.H., and L.W. Timmer. 1985. Rock phosphate as a source of phosphorus for vesiculararbuscular mycorrhizal development and growth of citrus in a soilless medium. J. Amer. Soc. Hort. Sci. 110:489-492.
Haselwandter, K., and G.D. Bowen. 1996. Mycorrhizal relations in trees for agroforestry and land rehabilitation. Forest Ecol. Manage. 81:1-17.

Jakobsen, I. 1994. Research approaches to study the functioning of vesicular-arbuscular mycorrhizas in the field. Plant Soll 159:141-147.

Johnson, C.R., J.N. Joiner, and C.E. Crews. 1980. Effects of $N, K$, and $M g$ on growth and leaf nutrient composition of three container grown woody ornamentals inoculated with mycorrhizae. J. Amer. Soc. Hort. Sci. 105:286-288.

Johnson, N.C. 1993. Can fertilization of soil select less mutualistic mycorrhizae? Ecol. Appl. 3:749-757.

Johnson, N.C., and F.L. Pfleger. 1992. Vesiculararbuscular mycorrhizae and cultural stresses, $p p$ 71-100. In Bethlenfalvay, G.J. and R.G. Linderman (Eds.). Mycorrhizae in Sustainable Agriculture. American Society of Agronomy, Madison, WI.

Mcarthur, D.A.J., and N.R. Knowles. 1993. Influence of species of vesicular-arbuscular mycorrhizal fungi and phosphorus nutrition on growth, development, and mineral nutrition of potato (Solanum tuberosum L). Plant Physiol. 102:771-782.

McGonigle, T.P., and M.H. Miller. 1993. Responses of mycorrhizae and shoot phosphorus of maize to the frequency and timing of soil disturbance. Mycorrhiza 4:63-68.

Moorman, T.B. 1989. A review of pesticide effects on microorganisms and microbial processes related to soil fertility. J. Prod. Agric. 2:14-23.

Nemec, S. 1987. VA mycorrhizae in horticultural systems, pp 193-211. In Safir, G.R. (Ed.). Ecophysiology of VA Mycorrhizal Plants. CRC Press, Boca Raton, FL.

Newsham, K.K., A.H. Fitter, and A.R. Watkinson. 1995. Multi-functionality and biodiversity in arbuscular mycorrhizas. Trends Ecol. Evol. 10:407-411.

O'Keefe, D.M., and D.M. Sylvia. 1991. Mechanisms of the vesicular-arbuscular mycorrhizal plantgrowth response, pp 35-53. In Arora, D.K., B. Rai, K.G. Mukerji, and G.R. Knudsen (Eds.). Handbook of Applied Mycology. Marcel Dekker, New York, NY.

Pope, P.E., W.R. Chaney, J.D. Rhodes, and S.H. Woodhead. 1983. The mycorrhizal dependency of four hardwood tree species. Can. J. Bot. 61: 412-417.

Read, D.J. 1992. The mycorrhizal mycelium, pp $102-$ 133. In Allen, M. (Ed.). Mycorrhizal functioning. Chapman Hall, New York, NY.

Sylvia, D.M. 1994. Vesicular-arbuscular mycorrhizal (VAM) fungi, pp 351-378. In Weaver, R.W., et al. (Eds.). Methods of Soil Analysis, Part 2. 
Microbiological and Biochemical Properties. Soil Science Society of America, Madison, WI.

Sylvia, D.M., and S.E. Williams. 1992. Vesiculararbuscular mycorrhizae and environmental stress, pp 101-124. In Linderman, R.G., and G.J. Bethlenfalvay (Eds.). Mycorrhizae in Sustainable Agriculture. Special Publication No. 54. American Society of Agronomy, Madison, WI.

Sylvia, D.M., D.O. Wilson, J.H. Graham, J.J. Maddox, P.P. Millner, J.B. Morton, H.D. Skipper, S.F. Wright, and A.G. Jarstfer. 1993. Evaluation of vesiculararbuscular mycorrhizal fungi in diverse plants and soils. Soil Biol. Biochem. 25:705-713.

Thompson, J.P. 1987. Decline of vesicular-arbuscular mycorrhizae in long fallow disorder of field crops and its expression in phosphorus deficiency of sunflower. Aust. J. Agric. Res. 38:847-867.

Trappe, J.M., R. Molina, and M.A. Castellano. 1984. Reactions of mycorrhizal fungi and mycorrhizal formation to pesticides. Annu. Rev. Phytopathol. 22:331-359.

Acknowledgements. Published as Florida Agricultural Experimental Station Journal Series No. R-6043. Partial support for this project was obtained from Walt Disney Imagineering Research and Development, Inc.

\section{1,2Soil and Water Science Department University of Florida Gainesville, FL 32611-0290}

\section{${ }^{3}$ Walt Disney Imagineering Research and Development, Inc. Box 1403, Cambridge MA 02142-0010}

\section{${ }^{4}$ Disney Animal Kingdom Landscape Walt Disney World, Co., Inc. Lake Buena Vista, FL 32810}

Résumé. Les associations de mycorrhizes fournissent un lien entre les racines de l'arbre et le sol, contribuant ainsi à la tolérance des arbres aux stress environnementaux. Cependant, peu de choses sont connues en ce qui touche l'état des mycorrhizes et la dépendance de plusieurs arbres ornementaux. Les objectifs de cette étude sont: 1) évaluer l'état des mycorrhizes sur des arbres ornementaux élevés en pépinière avant leur transplantation sur un site permanent en milieu urbain; 2) évaluer l'effet de l'environnement de croissance sur la formation de mycorrhizes. Un total de 23 espèces ont été étudiées: 9 cultivées en contenant et en plein champs, 6 cultivées uniquement en contenant, et 8 seulement en plein champs. Des interactions significatives entre les espèces d'arbres et l'environnement de croissance ont été découvertes pour la colonisation racinaire, le nombre de spores de mycorrhizes arbusculaires et les diamètres des radicelles. La proportion (par unité de longueur) de fines radicelles colonisées par des champignons de mycorrhizes s'étalait de $<20$ à près de 500 spores par $100 \mathrm{~g}$. Le diamètre moyen des fines radicelles variait de $<500$ à $>1,000 \mu \mathrm{m}$, et lorsqu'on comparait les végétaux élevés dans les deux milieux de croissance, ceux en plein champs avaient généralement des radicelles plus fines. La majorité des arbres ont formé des mycorrhizes du type arbusculaire; cependant, cinq espèces étaient de la famille des Pinacées ou des Fagacées et avaient donc le potentiel de former des ectomycorrhizes, mais elles en étaient pauvrement colonisées. Les pratiques culturales peuvent avoir eu un effet négatif sur le développement des ectomycorrhizes. Les faibles nombres de spores laissent aussi suggérer que les pratiques culturales peuvent avoir limité la formation de mycorrhizes arbusculaires sur les arbres en pépinière. Les recherches futures devrajent être focalisées directement sur la compréhension de l'importance des mycorrhizes sur les arbres ornementaux, incluant leur effet sur la survie des arbres et la croissance, ainsi que l'effet des applications d'engrais et de pesticides sur le développement des mycorrhizes.

Zusammenfassung. Die Verbindungen durch Mycorrhiza stellen eine Brücke zwischen Baumwurzeln und Boden dar und sie können dadurch zur Toleranz der Bäume gegenüber umweltbedingten Stress beitragen. Über den Status und die Abhängigkeit von Myccorhiza bei vielen Bäumen ist wenig bekannt. Die Ziele dieser Studie waren 1. den Status von Mycorrhiza bei Landschaftsbäumen, die in einer Baumschule gezogen wurden, vor dem Verpflanzen an einen permanenten Standort $z u$ untersuchen und 2. den Einfluß eines wüchsigen Umfeldes auf die Entwicklung von Mycorrhiza zu bewerten. Insgesamt wurden 23 Baumarten erfasst; neun Arten waren sowohl in Containern als auch im Boden, sechs Arten waren nur im Container und act Arten waren nur im Boden durch diese Studie präsent. Es wurden signifikante Interaktionen zwischen den Baumarten und dem Wachstumsmedium bezüglich der Kolonisation von Wurzeln, der Anzahl der arbuskularen Mycorrhiza-Sporen (AM) und des Feinwurzeldurchmessers. Die Proportionen der Feinwurzelen, die durch Mycorrhiza-Pilza vesiedelt waren, reichte von $<20$ bis zu fast 500 Sporen $100 \mathrm{~g}^{-1}$. Der mittlere Feinwurzeldurchmeser reichte von $<500$ bis $>1,000$ $\mu \mathrm{m}$ und wenn Pflanzen verglichen wurden, die in beiden Medien wuchsen, hatten die Wurzeln in der Tiefe einen großeren Feinwurzeldurchmesser. Die Mehrzahl der Bäume bildete arbuskuläre Mycorrhiza au. Trotzdem waren fünf Arten aus den Pinaceae und Fagaceae mit der Fähigkeit, Mycorrhiza zu formen, nur schwach kolonisiert. Kulturtechnische Maßnahmen könnten einen negativen Einfluß auf die Ausbildung von Ektomycorrhiza gehabt haben. Die reltiv nie3drigen Sporenzahlen verdeutlichen, daß Kulturmaßnahmen die Funktionen der AM-Pilze in Baumschulen beeinträchtigen können. Zukünftige Forschung sollte in Richtung eines Verständnisses der Bedeutung von Mycorrhiza für Bäume geleitet werden, einschließlich der Auswirkungen auf das Überleben und Wachstum der Bäume und der Einflüsse von Düngung und Pflanzenschutz auf die Entwicklung von Mycorrhiza. 
Resumen. Las asociaciones micorrízicas proveen un eslabonamiento entre las raices de los árboles y el suelo, de ese modo contribuyen a la tolerancia de los árboles al estrés ambiental. Poco, sin embargo, se conoce acerca del estado micorrízico o dependencia de muchos árboles en el paisaje. Los objetivos de este estudio fueron 1) evaluar el estado micorrízico de los árboles que crecen en granjas, antes del transplante a un sitio permanente y 2) evaluar el efecto del ambiente de crecimiento sobre la formación de micorrizas. Un total de 23 especies de árboles fueron muestreados: 9 estuvieron tanto en contenedores como en el terreno; 6 especies estuvieron en contenedores solamente y 8 especies estuvieron en el terreno solamente. Fueron encontradas interacciones significativas para la colonización de raíces, número de esporas del tipo micorrízico arbuscular (MA) y diámetro de las raíces finas, entre las especies de árboles y el ambiente de crecimiento. La proporción de elongación de raíces finas colonizadas por hongos micorrízicos varió de $<20$ a cerca de 500 esporas en $100 \mathrm{~g} \mathrm{~g}^{-1}$. Los diámetros de las raíces finas variaron de $<500$ a > 1,000 $\mu \mathrm{m}$, y cuando se compararon las plantas que crecieron en ambos ambientes, las del terreno generalmente tuvieron mayores diámetros de raíces finas. La mayoría de los árboles forman micorrizas del tipo arbuscular; sin embargo, 5 especies estuvieron en las Pinaceae o Fagaceae y tuvieron el potencial para formar ectomicorrizas, pero esos hospederos estuvieron pobremente colonizados. Las prácticas culturales pueden haber tenido un impacto negativo sobre el desarrollo de las ectomicorrizas. El número de esporas relativamente bajo sugiere que las prácticas culturales pueden empeorar la función de hongos MA en árboles de granja. La investigación futura debe ir dirigida hacia el entendimiento de la importancia de la micorriza para los árboles en el paisaje incluyendo efectos sobre sobrevivencia y crecimiento, y el efecto de fertilizar y la aplicación de pesticidas sobre el desarrollo micorrízico. 